\title{
Digital Literacy, Digital Competence and Research Productivity of Educators
}

\author{
Alberto D. Yazon ${ }^{1}$, Karen Ang-Manaig ${ }^{1, *}$, Chester Alexis C. Buama ${ }^{2}$, John Frederick B. Tesoro ${ }^{2}$ \\ ${ }^{1}$ College of Teacher Education, Laguna State Polytechnic University, Los Banos, Laguna, Philippines \\ ${ }^{2}$ College of Arts and Sciences, Laguna State Polytechnic University, Los Banos, Laguna, Philippines
}

Copyright $(2019$ by authors, all rights reserved. Authors agree that this article remains permanently open access under the terms of the Creative Commons Attribution License 4.0 International License

\begin{abstract}
This study determined the relationship between digital literacy, digital competence and research productivity of educators. This research employed the descriptive-correlational research design. The respondents of the study were the permanent faculty members of the university. The research instruments utilized were the standardized scales of Being Digital: Digital Literacy Checklist of The Open University (C) 2012 United Kingdom, measured the digital literacy of the respondents. And the digital competence was assessed through the Self-Assessment Tool of the European Digital Competence Framework for Educators (DigComEdu). The statistical tools used were the weighted mean, Standard Deviation and Chi-Square. The findings revealed that there is a strong and significant relationship between faculty members' digital literacy and research productivity. This means that the increase in understanding, finding, using, and creating information using digital technologies is positively related to faculty members' ability to conduct, complete, present and publish a research article. Likewise, faculty member's digital competence is strong and significantly correlated to their research productivity, which clearly indicates that as their knowledge, skills and attitudes for working, living and learning in the knowledge society increases, there is also a significant increase in their ability to produce publishable research outputs.
\end{abstract}

Keywords Digital Literacy, Digital Competence, Research Capability, Faculty Members

\section{Introduction}

The ability to read and write is the concept of being literate. These abilities would assure an individual to get a high-paying job or to obtain a higher education. In today's world, literacy goes beyond the ability to comprehend text. Students would need to master a new skill, Digital Literacy (Lynch, 2017). Shannon (2017) stated that Cornell
University defines digital literacy as an individual's ability to find, evaluate, utilize, share and create content using information technologies and the internet. Recent developments in Information and Communications Technology (ICT) have transformed how individuals learn. ICT has acquired a prominent role in the learning process, both in the educational system and at home (Meyers et al., 2013, Argentin, et. al., 2014). The Internet, in particular, has made available a virtually unlimited number of sources of information. As a result, the learning process increasingly requires the ability to access, locate, extract, evaluate, organize and present digital information (Argentin, et. al., 2014).

Digital literacy encompasses a wide range of skills, all of which are necessary to succeed in an increasingly digital world. At present, it plays an important role in the teaching and learning process. Educators are increasingly required to teach students with digital tools as their teaching aids.

In year 1997, Paul Glister popularized the term "Digital Literacy". He conceived it as simply "Literacy of Digital Age". Likewise, in the study conducted by Shannon (2017) that the concepts of digital literacy are the set of competencies required for full participation in a knowledge society. It includes devices such as smartphones, tablets, laptops, and desktop PCs for purposes of communication, expression, collaboration and advocacy. These definitions imply difference between knowledge and competency while in actual practice it is harder to pinpoint, particularly in the educational setting. Teachers are backed up with digital technology to make the curriculum enriched thereby enhancing the pedagogical approaches in the $21^{\text {st }}$ century classrooms.

Over the last few decades, the concepts of digital literacy and digital competence have been used more frequently and are increasingly discussed particularly in policy documents and policy-related discussions relevant to "what kind of skills and knowing people should have in a knowledge society, what to teach young people and how to do so (Ilomaki, Paavola \& Lakkala, 2016; cited by Spante, 2018). Consequently, Iordache, Marien \& Baeldon (2017) 
as cited by Spante (2018) that digital literacy and digital competence are used synonymously although they have distinct origins and meanings. Whereas in 2006, the European Commission (EC) stressed that sometimes they are used to underpin each other such as the European Union Framework of Key Competencies for all citizens, where digital competence is one of the eight key competencies.

The European Commission (EC) defined digital competence as it involves the confident and critical use of Information Society Technology (IST) for work, leisure and communication. It is underpinned by basic skills in Information and Communication Technology (ICT) that the use of computers to retrieve, assess, store, produce, present and exchange information and to communicate and participate in collaborative networks via the internet (Holmstrom, 2013). Clearly, it is indicated that digital competence is supported by digital literacy (Martin \& Grudziecki, 2006). In year 2013, the EC published a Digital Competence Framework based on the 5 areas and 21 competencies, which include the notion of digital literacy (Ferrari, 2013; as cited by Spante, 2018).

John King, U.S. Secretary of Education, mentioned that technology can be a powerful tool for transforming learning. One of the most important aspects of technology in education is its ability to level the field of opportunity for students. It can help affirm and advance relationships between educators and students, reinvent our approaches to learning and collaboration, shrink long-standing equity and accessibility gaps, and adapt learning experiences to meet the needs of all learners. Our schools, community colleges, adult learning centers and universities should be incubators of exploration and invention. Educators should be collaborators in learning, seeking new knowledge and constantly acquiring new skills alongside their students. Education leaders should set a vision for creating learning experiences that provide the right tools and supports for all learners to thrive. However, to realize fully the benefits of technology in our education system and provide authentic learning experiences, educators need to use technology effectively in their practice.

Digitally literate teachers and students should be able to carry out basic computer-based operations and access resources for everyday use. At the most basic level, a digitally literate person should be able to connect together a functional computer system for his/her own personal use, for example, a desktop to a printer. The ability to read manuals to conduct basic technical activities, or for troubleshooting, is part of being digitally literate. In addition to, or instead of reading manuals, digitally literate individuals are able to search for online resources that could assist with troubleshooting. Keying in the right questions in a search engine would enable the individual to retrieve responses in the form of text, images and videos that will assist with solving the problem. An understanding of the use of, and the regular updating of antivirus software to avoid spam and viruses, is also part of digital literacy learning (Ng, 2012).

Teachers' digital competencies have become an essential aspect of training teachers to promote learning in their students that moves away from the knowledge transfer model and moves towards a talent development model (Touron, et. al., 2018).

Research capability is the facility or potential of individuals, organizations, and systems to undertake and disseminate effectively and efficiently high quality research. It includes institutional consideration that covers the incentives, the economic, political and regulatory context and the resource based on which the context is built. Teaching in the higher education institutions mandates that all faculty members should perform the four-fold functions such as instruction, research, extension and production. In the same manner, the faculty members should be research driven and conscious.

As stated by Dela Cruz (2016) that research consciousness is recognized as an essential factor in affecting innovations. Any changes in the structure of education, school programs, projects and activities and in approaches and technique shall be first subjected to research because only research can provide factual bases of their effectiveness or ineffectiveness. In other words, all educational activities for total development are based on research.

At the Laguna State Polytechnic University, faculty members are required to conduct research as per performance indicator is concerned. The advent of digital technology paved the way in searching articles, journals and other scholarly articles are accessible to all. Most researchers would prefer to browse the Internet to seek for recent and relevant literature and studies.

It is in this light that the researchers intend to explore the relationships that may exist among digital literacy, digital competence and research capability of educators.

\subsection{Background of the Study}

Republic Act 7722 otherwise known as the Commission on Higher Education (CHED) mandates Higher Education Institutions (HEIs) to respond to the call of societal information. Dela Cruz (2016) cited the findings of Elman (1998) that the aim is to serve the poorest of the poor, the less privilege, the deprived and the oppressed. It is the primordial concern of every state university or college to implement the mandated functions in order to achieve sustainability in the community it serves and eventually improves the quality of life.

The Deakin University in Australia (n.d.) cited the findings of Hagel (2012) that digital literacy enhances our understanding on how to effectively and efficiently utilize the digital technologies in the teaching and learning process. Digital literacy is often understood differently depending on disciplines; however, fundamentally, it 
focuses more on literature rather than media and involves finding, using and disseminating information in a digital world.

Digital competence is one of the 8 key competencies identified by the European Commission (EC). It refers to the confidence and critical usage of the full range of digital technologies for information, communication and basic problem-solving in all aspects of life. As reported by the EC on their 2015 Digital Agenda Scoreboard, $40 \%$ of the European Union (EU) population has an insufficient level of digital competence, including $22 \%$ who do not use the Internet.

Further, the Eurydice Report in 2012 that almost all European countries have a specific national strategy related to digital competence. At the time of the study, digital competence was taught through a cross-curricular approach in all but two European Union countries at primary level and in all countries at secondary level - in addition to other approaches used in several countries such as integrating Information and Communication Technology (ICT) into particular subjects or teaching it as a separate subject. Providing teachers with sufficient digital competence is a key factor. The organization for Economic Cooperation and Development (School Education Gateway, 2017).

In the Philippines, the population has reached to 101 million (2015 Census) as reported by the Good Things Foundation (2016). Through this, an offline population of 63 million people (Worldbank, 2016) is identified. This ranks the country in $11^{\text {th }}$ in the world in terms of the total number of offline people. Thus, the impact for people who lack basic digital skills within an increasingly digital literate society is on employability and in searching, research articles that facilitates the teaching and learning process as well as in conducting and writing researches.

\subsection{Theoretical Framework}

This study was anchored in the Theory of John Dewey's (1938) Learning by Doing. Dewey believed that each child was active, inquisitive and wanted to explore. He stressed that learning should be active rather than passive. Education must engage with and enlarge experience, which has continued to be a significant strand in informal education practice. He believed that students could learn an enormous amount by participating in relevant experiences.

Similarly, this study was also based on the Experiential Learning Theory of David Kolb (1984). He believed that this type of learning could be defined as "the process whereby knowledge is created through the transformation of experience. Knowledge results from the combinations of grasping and transforming the experience". In this theory, it takes a more holistic approach and emphasizes how experiences, including cognition, environmental factors, and emotions, influence the learning process.

These theories are linked in an individual's digital literacy and competence as well as the capability of doing research.

\subsection{Conceptual Framework}

In the context of this study, the independent variables will be the Digital Literacy composed of understanding digital practices, finding information, using information, and creating information. In terms of digital competence, it contains the professional engagement, digital resources, teaching and learning, assessment, empowering learners and facilitating learners' digital competence. The dependent variables include the research productivity of educators in terms of proposed and approved research paper, completed research paper, presented research paper and published research paper.

\subsection{Statement of the Problem}

This study determined the relationship between digital literacy, digital competence and research productivity of educators.

Specifically, it sought to answer the following questions:

1. What is the mean score of the respondents in digital literacy in terms of:

- Understanding Digital Practices

- $\quad$ Finding Information

- Using Information

- Creating Information?

2. What is the mean score of the respondents in digital competence in terms of:

- Professional Engagement

- Digital Resources

- Teaching and Learning

- Assessment

- Empowering Learners

- Facilitating Learner's Digital Competence?

3. What is the mean score of the respondents in research productivity in terms of:

- $\quad$ Proposed and approved research paper

- Completed research paper

- Presented research paper

- Published research paper?

4. Is there a significant relationship between digital literacy and research productivity respondents?

5. Is there a significant relationship between digital competence and research productivity of the respondents?

\subsection{Hypotheses}

The study tested the following hypotheses:

There is no significant relationship between digital literacy and research productivity of the respondents.

There is no significant relationship between digital 
competence and research productivity of the respondents.

\subsection{Significance of the Study}

The results of the study will be beneficial to the following persons, agencies and entities:

The faculty members are the prime reason why this investigation is being pushed through. Whatever results revealed will definitely benefit them because they will be aware and cautious on how digitally literate and competent, they are particularly in integrating digital technology in conducting researches. Hence, this study will also provide students' digital literacy inventory/profile.

This research work could provide a significant contribution to the administrators in enhancing guidelines and policies geared toward the achievement of university's vision, mission, goals and objectives.

The findings of this research will provide bases in devising an instrument that could help in assessing the teaching force's literacy and competency in utilizing digital technologies.

The results of this study will contribute to the research productivity of LSPU. It will respond to the University's mission of providing quality and publishable research outputs.

\subsection{Scope and Limitation of the Study}

The researchers aimed to study Filipino teachers aged 30 to 50 years old. These target participants are currently employed as permanent faculty members at Laguna State Polytechnic University, Los Banos Campus. This study followed the cross-sectional procedure in data gathering. It did not include other factors and variables such as participants outside the intended age range and other variables not included in the paradigm. There would also be possible sources of extraneous variables such as response biases and anonymity.

\section{Materials and Methods}

\subsection{Research Design}

The study employed a Descriptive-Correlational research design to investigate relationships among two or more variables. In this design, it will reveal the significant relationship of the variables. This design focuses on the present condition and aims to find a new truth (Calmorin and Calmorin, 2010). This involves describing, analyzing, interpreting the present nature, composition and processes of a phenomenon.

\subsection{Population Sampling and Respondents of the Study}

The study employed the total enumeration for the respondents of the study. In practice, total population sampling is done when the target group is small and set apart by an unusual and well-defined characteristic.

\subsection{Research Procedure}

The study was conducted at the Laguna State Polytechnic University, Los Banos Campus. The researcher personally distributed the research instruments to all the target respondents. The said instruments were retrieved personally by the researcher after a week of distribution. Statistical analyses and interpretation of data followed the retrieval.

\subsection{Research Instrument}

This study utilized the standardized Being Digital: Digital Literacy Checklist of The Open University to measure the digital literacy of the respondents while the digital competence was assessed through the Self-Assessment Tool of the European Digital Competence Framework for Educators (DigComEdu). This tool is intended to help in teachers' progress towards digital age learning. Digital Competence for Educators (DigCompEdu) conceptual framework that describes what it means for educators to be digitally competent. The self-assessment tool is directed towards educators at all levels of education and provides teachers a tool for reflecting on their current take-up of digital technologies for innovative and effective learning. The said utilization of the instrument is through approval of Dr. Christine Redecker, author of the DigComEduc Framework. Research Productivity was assessed based on the actual count of the respondents' research outputs in the last three (3) years (2015-2018) with respect to publication, presentation, and completed research.

\subsection{Statistical Treatment of Data}

The gathered data were treated with statistical analyses. The following statistical analyses were used in the study:

Weighted mean and Standard Deviation in the analyses and interpretation of the measure digital literacy and digital competence of the respondents.

Chi-Square was used in testing the hypotheses of the study.

\section{Results and Discussions}

Table 1 presents faculty member's assessment on their digital literacy in terms of understanding digital practices.

As presented in Table 1, faculty members are quite competent in understanding digital practices $(x=2.17$; SD $=0.60$ ). This means that they are quite literate in knowing what categories of users they can expect to find online. They can quite explain what happens to information they put online. They are on average level on choosing the right 
tool to find, use, or create information. They also have a limited understanding on presenting themselves online, finding a person online, and using online tools and websites to find and record information online. Moreover, they admitted that they have quite knowledge on establishing who owns information and ideas they find online and establishing what online information they can legally re-use.

Table 1. Faculty member's assessment on their digital literacy in terms of understanding digital practices

\begin{tabular}{|c|c|c|c|c|}
\hline \multicolumn{2}{|r|}{ Indicative Statement } & \multirow{2}{*}{$\begin{array}{r}\text { Mean } \\
2.05\end{array}$} & \multirow{2}{*}{$\begin{array}{l}\text { SD } \\
0.71\end{array}$} & \multirow{2}{*}{ DI } \\
\hline 1. & $\begin{array}{l}\text { Knowing what categories of users } \\
\text { you can expect to find online }\end{array}$ & & & \\
\hline 2. & $\begin{array}{l}\text { Explaining what happens to } \\
\text { information you put online: your } \\
\text { digital footprint }\end{array}$ & 2.17 & 0.75 & QC \\
\hline 3. & $\begin{array}{l}\text { Choosing the right tool to find, use, } \\
\text { or create information. }\end{array}$ & 2.22 & 0.70 & QC \\
\hline 4. & $\begin{array}{l}\text { Presenting yourself online: your } \\
\text { digital identity. }\end{array}$ & 2.17 & 0.80 & QC \\
\hline 5. & $\begin{array}{l}\text { Finding a person online, for example } \\
\text { an expert in your discipline, and } \\
\text { establishing their contact details. }\end{array}$ & 2.21 & 0.67 & QC \\
\hline 6. & $\begin{array}{l}\text { Using online tools and websites to } \\
\text { find and record information online. }\end{array}$ & 2.24 & 0.71 & QC \\
\hline 7. & $\begin{array}{l}\text { Establishing who owns information } \\
\text { and ideas you find online. }\end{array}$ & 2.17 & 0.70 & QC \\
\hline o. & $\begin{array}{l}\text { Establishing what online } \\
\text { information you can legally re-use. }\end{array}$ & 2.12 & 0.73 & QC \\
\hline & Overall & 2.17 & 0.60 & QC \\
\hline
\end{tabular}

Legend: 2.50 - 3.00 - Very Confident (VC); 1.50 - 2.49 - Quite Confident (QC); $1.00-1.49$ - Not Confident (NC)

The findings relate to the statement of Shannon (2017) that the concepts of digital literacy are the set of competencies required for full participation in a knowledge society. It includes devices such as smartphones, tablets, laptops, and desktops (Personal Computer) for purposes of communication, expression, collaboration and advocacy. These definitions imply dichotomous stance between knowledge and competency while in actual practice it is harder to pinpoint, particularly in the educational setting. Teachers are backed up with digital technology to make the curriculum enriched thereby enhancing the pedagogical approaches in the $21^{\text {st }}$ century classrooms (deakin.edu.au).

Table 2 shows faculty member's assessment on their digital literacy in terms of finding information.

As shown in Table 2, faculty members are seemingly quite competent in finding information online $(x=2.33$; $\mathrm{SD}=0.56$ ). Although they are very competent in knowing what information you can find on the web, they lack competence in using online Library and advanced search options. They are quite familiar in using keywords to search for information online and using social networks as a source of information. They have little knowledge on knowing when to change their search strategy or when to stop searching. They cannot filter large numbers of search results quickly nor scanning/skimming a web page to get the relevant information quickly. They are not always keeping up-to-date with information from authoritative experts.

Table 2. Faculty members' on their digital literacy in terms of finding information

\begin{tabular}{|c|c|c|c|c|}
\hline \multicolumn{2}{|r|}{ Indicative Statement } & Mean & SD & DI \\
\hline 1. & $\begin{array}{l}\text { Knowing what information you can } \\
\text { find on the web. }\end{array}$ & 2.50 & 0.68 & $\mathrm{VC}$ \\
\hline 2. & $\begin{array}{l}\text { Knowing what information you can } \\
\text { find in an online Library. }\end{array}$ & 2.38 & 0.70 & QC \\
\hline 3. & $\begin{array}{l}\text { Using advanced search options to } \\
\text { limit and refine your search. }\end{array}$ & 2.38 & 0.70 & QC \\
\hline 4. & $\begin{array}{l}\text { Using keywords commonly used in } \\
\text { your discipline to search for } \\
\text { information online. }\end{array}$ & 2.38 & 0.67 & $\mathrm{QC}$ \\
\hline 5. & $\begin{array}{l}\text { Using social networks as a source of } \\
\text { information. }\end{array}$ & 2.47 & 0.63 & QC \\
\hline & $\begin{array}{l}\text { Knowing when to change your } \\
\text { search strategy or stop searching. }\end{array}$ & 2.34 & 0.64 & QC \\
\hline 7. & $\begin{array}{l}\text { Filtering large numbers of search } \\
\text { results quickly. }\end{array}$ & 2.14 & 0.74 & QC \\
\hline 8. & $\begin{array}{l}\text { Scanning / skimming a web page to } \\
\text { get to the key relevant information } \\
\text { quickly. }\end{array}$ & 2.31 & 0.78 & $\mathrm{QC}$ \\
\hline 9. & $\begin{array}{l}\text { Keeping up-to-date with information } \\
\text { from authoritative people or } \\
\text { organisations by subscribing to } \\
\text { Really Simple Syndication (RSS) } \\
\text { feeds. }\end{array}$ & 2.03 & 0.77 & QC \\
\hline & Overall & 2.33 & 0.56 & QC \\
\hline
\end{tabular}

Legend: $2.50-3.00$ - Very Confident (VC); $1.50-2.49$ - Quite Confident (QC); $1.00-1.49$ - Not Confident (NC)

It is true enough that the sheer influence and ubiquity of digital media mean that synthesis and critical assessment of a diverse array of resources are also key skills. Further, ethical and legal use of information and maintaining the security and privacy of the user's - and others' information are paramount. Digital literacy is not a stationary concept: as ICT changes, what it means to be digitally literate also needs to evolve to ensure that students develop and apply skills in appropriate new technologies for information discovery, transfer, analysis, review and communication (deakin.edu.au).

Table 3 reveals faculty member's assessment on their digital literacy in terms of using information.

The overall mean of $2.29(\mathrm{SD}=0.60)$, faculty members are quite competent in using available online information. This signifies that they lack proficiency in using different media and assessing the credibility and trustworthiness of their online source. They might be using other people's work (found online) with committing plagiarism due to inappropriate citation practices. They rarely keep record of the relevant details of information they find online. They 
have a limited background on using social bookmarking to organize and share information. Moreover, they might have committed illegal procedures of sharing files with others.

Table 3. Faculty member's assessment on their digital literacy in terms of using information

\begin{tabular}{|c|c|c|c|c|}
\hline \multicolumn{2}{|r|}{ Indicative Statement } & Mean & SD & DI \\
\hline 1. & $\begin{array}{l}\text { Using information in different } \\
\text { media, for example, podcasts or } \\
\text { videos. }\end{array}$ & 2.28 & 0.72 & $\mathrm{QC}$ \\
\hline 2. & $\begin{array}{l}\text { Assessing whether an online } \\
\text { resource (e.g. web page, blog, wiki, } \\
\text { video, podcast, academic journal } \\
\text { article) or person is credible and } \\
\text { trustworthy. }\end{array}$ & 2.33 & 0.73 & $\mathrm{QC}$ \\
\hline 3. & $\begin{array}{l}\text { Using other people's work (found } \\
\text { online) without committing } \\
\text { plagiarism. }\end{array}$ & 2.28 & 0.70 & QC \\
\hline 4. & $\begin{array}{l}\text { Citing a reference to an online } \\
\text { resource (e.g. in an assignment) } \\
\text { using the correct format. }\end{array}$ & 2.41 & 0.70 & QC \\
\hline 5. & $\begin{array}{l}\text { Keeping a record of the relevant } \\
\text { details of information you find } \\
\text { online. }\end{array}$ & 2.40 & 0.70 & QC \\
\hline 6. & $\begin{array}{l}\text { Using social bookmarking to } \\
\text { organise and share information. }\end{array}$ & 2.22 & 0.73 & QC \\
\hline 7. & Sharing files legally with others. & 2.12 & 0.80 & $\mathrm{QC}$ \\
\hline & Overall & 2.29 & 0.60 & QC \\
\hline
\end{tabular}

Legend: $2.50-3.00$ - Very Confident (VC); $1.50-2.49$ - Quite Confident (QC); 1.00 - 1.49 - Not Confident (NC)

This implies that the Internet, in particular, has made available a virtually unlimited number of sources of information. As a result, the learning process increasingly requires the ability to access, locate, extract, evaluate, organize and present digital information (Argentin, et.al. 2014).

Table 4 divulges faculty member's assessment on creating information as the last dimension of digital literacy.

With the lowest overall mean of $2.02(\mathrm{SD}=0.63)$, faculty members are quite competent in creating information. It indicates that they find difficulty in adding comments to blogs, forums or web pages, observing netiquette and appropriate social conventions for online communications. They barely write online for different audiences, e.g. a web page or blog entry for private use, for reading by your fellow students, for reading by your tutor, or for reading by anyone in the world. Apparently, they have a little knowledge on writing in different media for people to read on-screen and communicating with others online (forums, blogs, social networking sites, audio, video, etc.). As a result, they are quite competent in working with others online to create a shared document or presentation and using media-capture devices, e.g. recording and editing a podcast or video.
Table 4. Faculty member's assessment on their digital literacy in terms of creating information

\begin{tabular}{|ll|l|l|l|}
\hline \multicolumn{1}{|c|}{ Indicative Statement } & Mean & SD & DI \\
\hline 1. & $\begin{array}{l}\text { Adding comments to blogs, forums } \\
\text { or web pages, observing netiquette } \\
\text { and appropriate social conventions } \\
\text { for online communications. }\end{array}$ & 1.95 & 0.78 & QC \\
\hline $2 . \quad \begin{array}{l}\text { Writing online for different } \\
\text { audiences, e.g. a web page or blog } \\
\text { entry for private use, for reading by } \\
\text { your fellow students, for reading by } \\
\text { your tutor, or for reading by anyone } \\
\text { in the world. }\end{array}$ & 1.86 & 0.80 & QC \\
\hline $3 . \quad \begin{array}{l}\text { Writing in different media for people } \\
\text { to read on-screen. }\end{array}$ & 1.86 & 0.74 & QC \\
\hline $4 . \quad \begin{array}{l}\text { Communicating with others online } \\
\text { (forums, blogs, social networking } \\
\text { sites, audio, video, etc.) }\end{array}$ & 2.24 & 0.73 & QC \\
\hline $5 . \quad \begin{array}{l}\text { Working with others online to create } \\
\text { a shared document or presentation. }\end{array}$ & 2.28 & 0.72 & QC \\
\hline $6 . \quad \begin{array}{l}\text { Using media-capture devices, e.g. } \\
\text { recording and editing a podcast or } \\
\text { video. }\end{array}$ & 1.93 & 0.77 & QC \\
\hline & $\mathbf{2 . 0 2}$ & $\mathbf{0 . 6 3}$ & QC \\
\hline
\end{tabular}

Legend: $2.50-3.00-$ Very Confident (VC); $1.50-2.49$ - Quite Confident (QC); $1.00-1.49$ - Not Confident (NC)

Generally, the faculty - respondents of this study assessed themselves as quite competent in manipulating and gathering data through digital technologies. They reported limited skills on understanding digital practices, finding Information, using Information and creating Information.

Table 5 highlights faculty member's assessment on their digital competence in terms of professional engagement.

Table 5. Faculty member's assessment on their digital competence in terms of professional engagement

\begin{tabular}{|ll|c|c|c|}
\hline \multicolumn{2}{|c|}{ Indicative Statement } & Mean & SD & DI \\
\hline 1. $\begin{array}{l}\text { I systematically use different digital } \\
\text { channels to enhance communication } \\
\text { with students, parents and colleagues: } \\
\text { e.g. emails, blogs, the school's } \\
\text { website, Apps }\end{array}$ & 3.71 & 1.31 & O \\
\hline 2. $\begin{array}{l}\text { I use digital technologies to work } \\
\text { together with colleagues inside and } \\
\text { outside my educational organisation. }\end{array}$ & 3.88 & 1.16 & O \\
\hline 3. $\begin{array}{l}\text { I actively develop my digital teaching } \\
\text { skills }\end{array}$ & 3.53 & 1.25 & O \\
\hline 4. $\begin{array}{l}\text { I participate in online training } \\
\text { opportunities e.g. online courses, } \\
\text { MOOCs, webinars... }\end{array}$ & 2.72 & 1.44 & S \\
\hline \multicolumn{1}{|l|}{ Overall } & $\mathbf{3 . 4 6}$ & $\mathbf{1 . 0 4}$ & S \\
\hline
\end{tabular}

Legend: 4.50 - 5.00 - Always (A); 3.50 - 4.49 - Often (O); 2.50 - 3.49 Sometimes (S); 1.50 - 2.49 - Rarely; $1.00-1.49-\operatorname{Never}(\mathrm{N})$

As highlighted in Table 5, faculty members are 
sometimes engaging on online activities as an avenue of professional growth and development $(x=3.46 ; \mathrm{SD}=$ 1.04). This means that they sometimes participate in online training opportunities, which seemingly affected their overall assessment on this construct of digital competence. Nevertheless, they often use different digital channels to enhance communication with other stakeholders, which eventually develop their digital teaching skills.

Thus, Holmstrom (2013) stated that digital competence, as an understanding of how digital technology works, together with the opportunities, makes people live in an information society. This competence states that people should be able to use digital technology in order to support creativity and innovation. A prerequisite for using this technology is that the user adopts a critical and responsible approach to information and interactive media.

Table 6 indicates faculty member's assessment on their digital competence in terms of digital sources.

Table 6. Faculty member's assessment on their digital competence in terms of digital resources

\begin{tabular}{|c|c|c|c|c|}
\hline \multicolumn{2}{|c|}{ Indicative Statement } & Mean & SD & DI \\
\hline 1. $\begin{array}{l}\text { I use different internet sites and } \\
\text { search strategies to find and select a } \\
\text { range of different digital resources. }\end{array}$ & 4.05 & 1.13 & O \\
\hline 2. $\quad \begin{array}{l}\text { I create my own digital resources and } \\
\text { modify existing ones to adapt them to } \\
\text { my needs }\end{array}$ & 2.90 & 1.37 & $\mathrm{~S}$ \\
\hline $\begin{array}{l}\text { I effectively protect sensitive content, } \\
\text { e.g. exams, students' grades, personal } \\
\text { data }\end{array}$ & 3.69 & 1.57 & $\mathrm{O}$ \\
\hline \multicolumn{1}{|c|}{ Overall } & $\mathbf{3 . 5 5}$ & $\mathbf{1 . 1 1}$ & $\mathbf{O}$ \\
\hline
\end{tabular}

Legend: 4.50 - 5.00 - Always (A); $3.50-4.49$ - Often $(\mathrm{O}) ; 2.50-3.49$ Sometimes (S); 1.50 - 2.49 - Rarely; $1.00-1.49$ - Never (N)

As reflected in Table 6, faculty members often use different internet sites and search strategies to find and select a range of different digital resources. According to them, oftentimes they effectively protect sensitive content, e.g. exams, students' grades, personal data. Although they sometimes create their own digital resources and modify existing ones to adapt them to their needs, their overall digital competence in terms of digital resources is satisfactory $(x=3.55 ; \mathrm{SD}=1.11)$.

Thus, it can be deduced that as stated by Touron, et al. (2018) that teaching competencies could be defined as the set of knowledge, personal traits, attitudes, and skills that make it possible to perform educational actions, generally recognisably pragmatic in nature, relating to achievement in the field of education (Touron et al, 2018 cited Álvarez Rojo, 2010).

Table 7 discloses faculty member's assessment on their digital competence in terms of teaching and learning.

As presented in Table 7, faculty members_have assessed a middling "value" of digital technologies $(x=2.96 ; \mathrm{SD}=$ 1.40 ), although they carefully consider how, when and why to use digital technologies in class. This is evident when they reported that they sometimes monitor students' activities and interactions in the collaborative online environments they use. When their students work in groups or teams, they sometimes use digital technologies to acquire and document evidence. They also sometimes use digital technologies to allow students to plan, document and monitor their learning themselves such as quizzes for self-assessment, ePortfolios for documentation and showcasing, online diaries/blogs for reflection.

Table 7. Faculty member's assessment on their digital competence in terms of teaching and learning

\begin{tabular}{|c|c|c|c|c|}
\hline \multicolumn{2}{|r|}{ Indicative Statement } & \multirow{2}{*}{$\begin{array}{l}\text { Mean } \\
3.52\end{array}$} & \multirow{2}{*}{$\begin{array}{l}\text { SD } \\
1.49\end{array}$} & \multirow{2}{*}{$\begin{array}{l}\text { DI } \\
\mathrm{O}\end{array}$} \\
\hline 1. & $\begin{array}{l}\text { I carefully consider how, when and } \\
\text { why to use digital technologies in } \\
\text { class, to ensure that they are used } \\
\text { with added value. }\end{array}$ & & & \\
\hline 2. & $\begin{array}{l}\text { I monitor my students' activities and } \\
\text { interactions in the collaborative } \\
\text { online environments we use }\end{array}$ & 2.74 & 1.49 & $\mathrm{~S}$ \\
\hline 3. & $\begin{array}{l}\text { When my students work in groups or } \\
\text { teams, they use digital technologies } \\
\text { to acquire and document evidence }\end{array}$ & 2.95 & 1.54 & $\mathrm{~S}$ \\
\hline 4. & $\begin{array}{l}\text { I use digital technologies to allow } \\
\text { students to plan, document and } \\
\text { monitor their learning themselves } \\
\text { E.g. quizzes for self-assessment, } \\
\text { ePortfolios for documentation and } \\
\text { showcasing, online diaries/blogs for } \\
\text { reflection... }\end{array}$ & 2.64 & 1.58 & $\mathrm{~S}$ \\
\hline & Overall & 2.96 & 1.40 & $\mathbf{S}$ \\
\hline
\end{tabular}

Legend: 4.50 - 5.00 - Always (A); 3.50 - 4.49 - Often (O); 2.50 - 3.49 Sometimes (S); 1.50 - 2.49 - Rarely; $1.00-1.49$ - Never (N)

Table 8 exposes faculty member's assessment on their digital competence in terms of assessment of learning.

Table 8. Faculty member's assessment on their digital competence in terms of assessment of learning

\begin{tabular}{|c|c|c|c|c|}
\hline \multicolumn{2}{|r|}{ Indicative Statement } & Mean & SD & DI \\
\hline 1. & $\begin{array}{l}\text { I use digital assessment formats to } \\
\text { monitor student progress. }\end{array}$ & 2.71 & 1.64 & $\mathrm{~S}$ \\
\hline 2. & $\begin{array}{l}\text { I analyse all data available to me to } \\
\text { timely identify students who need } \\
\text { additional support.. } \\
\text { Data" includes: students' } \\
\text { engagement, performance, grades, } \\
\text { attendance; activities and social } \\
\text { interactions in (online) environments; } \\
\text { "Students who need additional } \\
\text { support" are: students who are at risk } \\
\text { of dropping out or underperforming; } \\
\text { students who have learning disorders } \\
\text { or specific learning needs, students } \\
\text { who lack transversal skills, e.g. } \\
\text { social, verbal or study skills. }\end{array}$ & 2.78 & 1.59 & $\mathrm{~S}$ \\
\hline & Overall & 2.74 & 1.56 & $\mathbf{S}$ \\
\hline
\end{tabular}

Legend: 4.50 - 5.00 - Always (A); 3.50 - 4.49 - Often (O); 2.50 - 3.49 Sometimes (S); $1.50-2.49$ - Rarely; $1.00-1.49-$ Never $(\mathrm{N})$

As presented in Table 8, faculty members sometimes use 
digital assessment formats to monitor students' progress. They also sometimes analyse all data available to them to timely identify students who need additional support. In the principle of assessment of students' learning, faculty members have shown limited competence and accountability in integrating digital technologies $(x=2.74$; $\mathrm{SD}=1.56)$.

Table 9 pinpoints faculty member's assessment on their digital competence in terms of empowering learners.

Table 9. Faculty member's assessment on their digital competence in terms of empowering learners

\begin{tabular}{|c|c|c|c|c|}
\hline \multicolumn{2}{|r|}{ Indicative Statement } & Mean & SD & DI \\
\hline 1. & $\begin{array}{l}\text { When I create digital assignments for } \\
\text { students I consider and address } \\
\text { potential digital problems E.g. equal } \\
\text { access to digital devices and } \\
\text { resources; interoperability and } \\
\text { conversion problems; lack of digital } \\
\text { skills }\end{array}$ & 2.98 & 1.69 & $\mathrm{~S}$ \\
\hline 2. & $\begin{array}{l}\text { I use digital technologies to offer } \\
\text { students personalised learning } \\
\text { opportunities. } \\
\text { e.g. I give different students different } \\
\text { digital tasks to address individual } \\
\text { learning needs, preferences and } \\
\text { interests. }\end{array}$ & 2.81 & 1.54 & $\mathrm{~S}$ \\
\hline 3. & $\begin{array}{l}\text { I use digital technologies for students } \\
\text { to actively participate in class }\end{array}$ & 2.97 & 1.58 & $\mathrm{~S}$ \\
\hline & Overall & 2.92 & 1.53 & $\mathbf{S}$ \\
\hline
\end{tabular}

Legend: 4.50 - 5.00 - Always (A); $3.50-4.49$ - Often (O); $2.50-3.49$ Sometimes (S); 1.50 - 2.49 - Rarely; $1.00-1.49$ - Never (N)

The overall mean assessment of $2.92(\mathrm{SD}=1.53)$ tells that faculty members sometimes consider and address potential digital problems such as equal access to digital devices and resources; interoperability and conversion problems; lack of digital skills when they create digital assignments for students. They sometimes use digital technologies to offer students personalised learning opportunities such as giving different students different digital tasks to address individual learning needs, preferences and interests. In effect, they sometimes use digital technologies for students to actively participate in class.

Table 10 shows faculty member's assessment on their digital competence in terms of facilitating learner's digital competence.

Table 10. Teacher's assessment on their digital competence in terms of facilitating learner's digital competence

\begin{tabular}{|c|c|c|c|}
\hline Indicative Statement & Mean & SD & DI \\
\hline $\begin{array}{l}\text { 1. I teach students how to assess the } \\
\text { reliability of information and to } \\
\text { identify misinformation and bias }\end{array}$ & 3.03 & 1.65 & $\mathrm{~S}$ \\
\hline $\begin{array}{l}\text { 2. I set up assignments, which require } \\
\text { students to use digital means to } \\
\text { communicate and collaborate with } \\
\text { each other or with an outside } \\
\text { audience. }\end{array}$ & 3.02 & 1.61 & $\mathrm{~S}$ \\
\hline $\begin{array}{l}\text { 3. I set up assignments, which require } \\
\text { students to create digital content e.g. } \\
\text { videos, audios, photos, digital } \\
\text { presentations, blogs, wikis. }\end{array}$ & 3.09 & 1.58 & $\mathrm{~S}$ \\
\hline $\begin{array}{l}\text { 4. I teach students how to behave safely } \\
\text { and responsibly online. }\end{array}$ & 3.28 & 1.55 & $\mathrm{~S}$ \\
\hline $\begin{array}{l}\text { 5. I encourage students to use digital } \\
\text { technologies creatively to solve } \\
\text { concrete problems. e.g. to overcome } \\
\text { obstacles or challenges emerging in } \\
\text { the learning process. }\end{array}$ & 3.12 & 1.59 & $\mathrm{~S}$ \\
\hline Overall & 3.11 & 1.49 & $\mathbf{S}$ \\
\hline
\end{tabular}

Legend: 4.50 - 5.00 - Always (A); $3.50-4.49$ - Often (O); 2.50 - 3.49 Sometimes (S); 1.50 - 2.49 - Rarely; $1.00-1.49$ - Never (N)

As illustrated in Table 10, faculty members have insufficient competence in facilitating learners' digital competence $(x=3.11$; SD $=1.49)$. According to them, they sometimes teach students how to assess the reliability of information and to identify misinformation and bias. Also, they sometimes set up assignments which require students to use digital means to communicate and collaborate with each other or with an outside audience. Similarly, they reported that they sometimes set up assignments, which require students to create digital content e.g. videos, audios, photos, digital presentations, blogs, wikis. Seemingly, they sometimes teach students how to behave safely and responsibly online and they occasionally encourage students to use digital technologies creatively to solve concrete problems such as to overcome obstacles or challenges emerging in the learning process.

Table 11 reveals the research productivity of faculty members in the last two semesters a year preceding the survey. 
Table 11. Research productivity of faculty members in the last two semesters a year preceding the survey

\begin{tabular}{|c|c|c|c|c|c|}
\hline \multirow[b]{2}{*}{ University Unit } & \multicolumn{3}{|c|}{ Frequency (\%) } & \multirow[b]{2}{*}{ Productivity* } & \multirow[b]{2}{*}{ Remarks } \\
\hline & $\begin{array}{l}\text { w/ completed } \\
\text { research }\end{array}$ & w/ presentation & w/ publication & & \\
\hline CTE $(n=17)$ & $64.7 \%$ & $41.2 \%$ & $41.2 \%$ & $6.88 \pm 6.58$ & $\begin{array}{l}\text { Moderately } \\
\text { Productive }\end{array}$ \\
\hline CFND $(n=6)$ & $16.7 \%$ & $16.7 \%$ & $0.00 \%$ & $1.33 \pm 3.27$ & Unproductive \\
\hline CBMA $(n=6)$ & $33.3 \%$ & $33.3 \%$ & $0.00 \%$ & $2.67 \pm 4.13$ & Unproductive \\
\hline CHMT $(n=6)$ & $50.0 \%$ & $16.7 \%$ & $0.00 \%$ & $2.33 \pm 3.14$ & Unproductive \\
\hline CAS $(n=7)$ & $42.9 \%$ & $42.9 \%$ & $14.3 \%$ & $4.43 \pm 6.00$ & Less Productive \\
\hline $\mathrm{COF}(\mathrm{n}=9)$ & $66.7 \%$ & $33.3 \%$ & $11.1 \%$ & $4.44 \pm 5.03$ & Less Productive \\
\hline $\operatorname{CCS}(n=5)$ & $100.0 \%$ & $20.0 \%$ & $20.0 \%$ & $5.40 \pm 5.37$ & $\begin{array}{l}\text { Moderately } \\
\text { Productive }\end{array}$ \\
\hline $\begin{array}{c}\text { OVERALL } \\
(\mathrm{n}=56)\end{array}$ & $55.4 \%$ & $32.1 \%$ & $17.9 \%$ & $6.02 \pm 5.51$ & $\begin{array}{l}\text { Moderately } \\
\text { Productive }\end{array}$ \\
\hline
\end{tabular}

*PRODUCTIVITY: $<3.00$ - not productive; $\geq 3.00-5.00$ - less productive; $>5.00-10.00$ - moderately productive; $>10.0-15.00$ - highly productive

As reflected in Table 5, only two (2) out of seven (7) Colleges surveyed are moderately productive in terms of the number of completed, presented, and published researches which carry over the overall research productivity of LSPU-LB Campus. However, it can be observed that empowering faculty members in terms of research productivity is still wanting in most of the University Units.

Table 12 reveals the test of significant relationship between faculty member's digital literacy, digital competence, and research productivity.

Table 12. Test of significant relationship between faculty member's digital literacy, digital competence, and research productivity.

\begin{tabular}{|c|c|c|}
\hline Variables & df & $\mathbf{X}^{\mathbf{2}}$ value \\
\hline Digital literacy and research productivity & 8 & $50.938^{* *}$ \\
\hline Digital competence and research productivity & 4 & $45.214 * *$ \\
\hline
\end{tabular}

**Significant at $\mathrm{p}<.01$

As revealed in Table 12, there is a strong and significant relationship between faculty members' digital literacy and research productivity $\left(\mathrm{X}^{2}(\mathrm{df}=8), 50.938\right)$ which means that the increase in understanding, finding, using, and creating information using digital technologies is positively related to faculty members' ability to conduct, complete, present and publish a research article. In the same vein, faculty member's digital competence is strong and significant correlated to their research productivity, which clearly indicates that as their knowledge, skills and attitudes for working, living and learning in the knowledge society increases, there is also a significant increase in their ability to produce publishable research outputs.

\section{Conclusions and Recommendations}

\subsection{Conclusions}

Based on the findings of the study, the conclusions were drawn:

There is a strong and significant relationship between faculty members' digital literacy and research productivity. This means that the increase in understanding, finding, using, and creating information using digital technologies is positively related to faculty members' ability to conduct, complete, present and publish a research article. Likewise, faculty member's digital competence is strong and significantly correlated to their research productivity, which clearly indicates that as their knowledge, skills and attitudes for working, living and learning in the knowledge society increases, there is also a significant increase in their ability to produce publishable research outputs. Moreover, teacher's educational level of academic, organizational title, job description, age, years of experience in teaching and non-teaching roles, research interests, may play a vital role in their digital competence, digital literacy, and research productivity.

\subsection{Recommendations}

In view of the findings and conclusions of the study, it is recommended that:

1. The university may implement series of seminar-workshops on technology for teaching and learning to improve the digital literacy and digital competence of the faculty members.

2. Fast internet connection to all faculty room may be installed so that faculty members can browse scholarly online journals thereby increasing their research capability.

3. A follow-up study may be undertaken to monitor faculty members' digital literacy, digital competence and research productivity.

\section{Acknowledgements}

This research paper was supported by the Laguna State 
Polytechnic University.

\section{REFERENCES}

[1] Anon. (2017) Digital competence: the vital 21st-century skill for teachers and students. Retrieved fromhttps://www.scho oleducationgateway.eu/en/pub/resources/tutorials/digital-c ompetence-the-vital-.htm

[2] Anon. (n.d.) Digital Literacy. Retrieved from: www.keyconet.eun.org/digital

[3] Anon.(n.d.) Digital Literacy Retrived from: http://www.dea kin.edu.au/_data/assets/pdf_file/0008/1237742/digital-lite racy.pdf

[4] Argentin, G., Gui, M., Pagani, L. \& Stanca, L. (2014) The Impact of Digital Literacy on Educational Outcomes: Evidence from Performance Tests. http://www.aiel.it/Old/bacheca/Pisa/papers/pagani.pdf

[5] Chang, W.W. M. (2016) Digital Competence and Professional Development of Vocational Education and Training Teachers in Queensland. Retrieved from: https://eprints.qut.edu.au/95088/1/Wei-Wei_Chang_Thesis .pdf

[6] De la Cruz, J.L. (2016) The Research Capability of Ilocos Sur Polytechnic State College: A Basis for A Capability Enhancement Program. International Journal of Management and Social Sciences Research (IJMSSR) ISSN: 2319-4421 Volume 5, No. 7, July 2016. http://www.irjcjou rnals.org/ijmssr/July2016/6.pdf

[7] European Commission (2019) DiGiComEdu. Retrieved from https://ec.europa.eu/jrc/en/digcompedu

[8] Holmstrom, T. \& Siljebo, J. (2013) Developing digital competence or exploring teaching with digital technologies? An organizational study of municipalities' development of upper secondary school students' digital competence.

[9] Instefjord, E. J. (2018) Professional Digital Competence in Education. Retrieved from: https://brage.bibsys.no/xmlui/b itstream/hhttp://www.divaportal.org/smash/get/diva2:6319 46/FULLTEXT02andle/11250/2501440/Elen_J_Instefjord. pdf? sequence $=1 \&$ is Allowed $=\mathrm{y}$

[10] Koyunco, M. (2011) The Impact of Digital Competence on Academic Performance of Students. International Multidisciplinary Scientific GeoConference: SGEM: Surveying Geology \& mining Ecology Management; Sofia Vol. 3: 1295-1299. Sofia: Surveying Geology \& Mining Ecology Management (SGEM). (2011) Retrieved from https://search.proquest.com/openview/03bfc8bcf53b17b71 b719b366able6e8/1.pdf?pq-origsite $=$ gscholar\&cbl=15363 38

[11] Lynch, M. (2017). What is Digital Literacy? Retrieved from https://www.thetechedvocate.org/what-is-digital-literacy/

[12] Ng, W. (2012) Why digital literacy is important for science teaching and learning? Curriculum and Leadership Journal Vol. 19 Issue 10. Retrieved from http://www.curriculum.e du.au/leader/why_digital_literacy_is_important_for_scienc e teac, 34913.html?issue $\overline{I D}=12610$
[13] Shannon, S. (2017) Teacher Perceptions of Digital Literacy in an L2 Classroom. Retrieved from: https://muep.mau.se/ bitstream/handle/2043/23380/EnesThesis90\%20BS.pdf?se quence $=2$

[14] Shopova T. (2014) "Digital Literacy of Students and Its Improvement at the University", Journal on Efficiency and Responsibility in Education and Science, Vol. 7, No. 2, pp. 26-32, online ISSN 1803-1617, printed ISSN 1803-1617, DOI: $10.7160 /$ eriesj.2014.070201

[15] Spante et al., Cogent Education (2018), 5: 1519143 https://doi.org/10.1080/2331186X.2018.1519143

[16] Tourón, J., Martín, D., Navarro, E., Pradas, S. and Íñigo, V. (2018). Validación de constructo de un instrumento para medir la competencia digital docente de los profesores (CDD) $\mid$ Construct validation of a questionnaire to measure teachers' digital competence (TDC). Revista Española de Pedagogía, 76 (269), 25-54. doi: https://doi.org/10.22550/ REP76-1-2018-02 